\title{
Pengaruh Edukasi Kesehatan Paket Cerdas Ibu Menyusui (PCIM) terhadap Efikasi Diri Ibu Primipara dalam Merawat Bayi Baru Lahir di Haharu, Sumba Timur
}

\section{The Influence of PCIM Health Education Module on The Self-Efficacy of Primiparous in Taking Care of Newborn in Haharu, East Sumba}

\author{
Umbu Nggiku Njakatara' ${ }^{1}$, Lely Lusmilasari ${ }^{2}$, Anik Rustiyaningsih ${ }^{2}$ \\ ${ }^{1}$ Program Studi Keperawatan Waingapu, Poltekkes Kemenkes Kupang, Nusa Tenggara Timur \\ ${ }^{2}$ Departemen Keperawatan Anak dan Maternitas, Fakultas Kedokteran, Kesehatan \\ Masyarakat, dan Keperawatan, Universitas Gadjah Mada, Yogyakarta
}

\begin{abstract}
Background: Maternal self-efficacy is a mother's ability to manage her role. This ability has a positive impact towards children's safety and development. Knowledge to take care of newborn will increase maternal self-efficacy, especially for primiparous (a woman who is pregnant or gives birth for the first time). Health education may be one effective way, among others, to deliver this knowledge.

Objective: To examine the effect of a health education module called Paket Cerdas Ibu Menyusui/PCIM (translated as breastfeeding smart package) toward self-efficacy of primiparous in caring newborns. The second objective is to examine the corelation between social support and maternal self-efficacy.

Method: This research used a quasi-experimental with pre-test and post-test for comparing intervention, and a control grup. There were 60 primiparous who became participants which were selected by consecutive sampling techniques. Research instruments were PSES scale for primiparous self-efficacy and PSSP for social support measurement. Data analysis were using paired t-test, independent t-test and Spearman test with significance level or $p$ value $<0,05$.

Results: PCIM health education module affected maternal self-efficacy score. Respondents received scores of 3,51 before intervention and increased into 5,49 after intervention $(p=0,001)$. The increasement in intervention group was higher than control group $(p=0,001)$. On the other hand, there was not any significant correlation between social supprot and self-efficacy for both groups $(p>0,05)$.

Conclusion: PCIM health education module increases the self-efficacy of primiparous in caring for newborns. But, there is not any correlation between social support and the self-efficacy of primiparous in caring for newborns.
\end{abstract}

Keywords: Breastfeeding Smart Package, maternal self-efficacy, social support

\begin{abstract}
ABSTRAK
Latar Belakang: Efikasi diri ibu merupakan keyakinan seorang ibu akan kemampuannya dalam menjalankan peran yang dapat memberi pengaruh positif terhadap keselamatan dan perkembangan anaknya. Untuk meningkatkan keyakinan ibu, khususnya pada ibu primipara (perempuan yang pertama kali hamil atau melahirkan bayi) diperlukan pengetahuan dalam merawat bayi baru lahir yang dapat dilakukan melalui edukasi kesehatan.

Tujuan: Untuk mengetahui pengaruh edukasi kesehatan paket cerdas ibu menyusui terhadap efikasi diri ibu primipara dalam merawat bayi baru lahir, dan hubungan dukungan sosial dengan efikasi diri ibu primipara.

Metode: Penelitian ini menggunakan rancangan quasi experiment pre-test and post-test dengan kelompok kontrol. Subjek penelitian berjumlah 60 ibu primipara yang dipilih menggunakan teknik consecutive sampling. Penelitian ini menggunakan instrumen PSES untuk mengukur efikasi diri ibu primipara dalam merawat bayi baru lahir dan PSSP untuk melihat hubungan dukungan sosial dengan efikasi diri ibu. Analisis data menggunakan uji paired $t$-test, independent $t$-test dan Spearman dengan tingkat kemaknaan $\mathrm{p}<0,05$.
\end{abstract}

Corresponding Author: Umbu Nggiku Njakatara

Kambajawa, Waingapu, Kabupaten Sumba Timur, Nusa Tenggara Timur 87116

Email: umbu.nggiku.n@mail.ugm.ac.id 
Hasil: Edukasi kesehatan paket cerdas ibu menyusui berpengaruh terhadap efikasi diri ibu primipara dalam merawat bayi baru lahir dengan nilai 3,51 sebelum intervensi, menjadi 5,49 setelah intervensi dengan nilai $(p=0,001)$. Peningkatan efikasi diri pada kelompok intervensi lebih tinggi dari kelompok kontrol $(p=0,001)$. Tidak terdapat hubungan yang signifikan antara dukungan sosial dengan efikasi diri pada kedua kelompok $(\mathrm{p}>0,05)$.

Kesimpulan: Edukasi kesehatan paket cerdas ibu menyusui memengaruhi peningkatan efikasi diri ibu primipara dalam merawat bayi baru lahir. Dukungan sosial tidak berhubungan dengan peningkatan efikasi diri ibu primipara.

Kata kunci: dukungan sosial, edukasi kesehatan, efikasi diri ibu, Paket Cerdas Ibu Menyusui

\section{PENDAHULUAN}

Efikasi diri ibu merupakan keyakinan seorang ibu terhadap kemampuan dirinya untuk menampilkan tingkah laku yang akan mengarahkan pada hasil yang diharapkan. Keyakinan diri ibu merupakan persepsi atau keyakinan akan kemampuannya dalam menjalankan peran sebagai seorang ibu yang berpengaruh positif terhadap perilaku, keselamatan, dan perkembangan anaknya. ${ }^{1}$

Pentingnya efikasi diri ibu dalam merawat bayi baru lahir seperti menyusui, telah dibuktikan oleh beberapa penelitian. Penelitian yang dilakukan oleh Pollard dan Guill ${ }^{2}$ menemukan bahwa terdapat hubungan antara tingkat efikasi diri dalam menyusui dengan durasi menyusui. Sementara, penelitian yang dilakukan oleh Dennis ${ }^{3}$ menunjukkan hasil bahwa ibu dengan tingkat efikasi diri yang kurang dalam memberikan ASI, secara signifikan mengalami hambatan pemberian ASI dalam dua minggu postpartum. Hal yang sama juga dikemukakan oleh Buxton et al. ${ }^{4}$ yang menjelaskan bahwa $27 \%$ wanita dengan tingkat efikasi diri rendah dalam pemberian ASI pada masa prenatal, akan menghentikan pemberian ASI dalam 1 minggu postpartum. Kegagalan pemberian ASI terjadi 4-5 kali lebih tinggi pada wanita yang kurang percaya diri dalam pemberian ASI pada bayi baru lahir. ${ }^{5}$

Pengetahuan merupakan salah satu faktor yang dapat meningkatkan efikasi diri ibu postpartum primipara. Kurangnya pengetahuan dan keterampilan yang dimiliki lbu, akan memengaruhi ibu dalam melakukan perawatan pada bayi. ${ }^{6}$

Beberapa hasil penelitian dalam negeri maupun luar negeri menyatakan bahwa efikasi diri ibu dapat ditingkatkan dengan edukasi kesehatan. Penelitian yang dilakukan oleh Citrawati ${ }^{7}$ menyatakan bahwa edukasi kesehatan audiovisual dapat meningkatkan efikasi diri ibu primipara dalam menyusui bayi baru lahir. Sementara Joventino, ${ }^{8}$ menyatakan bahwa edukasi kesehatan menggunakan audiovisual dapat meningkatkan efikasi diri ibu dalam merawat bayi dan mencegah infeksi pada bayi. Adapun data pendukung dari Puskesmas Rambangaru Kecamatan Haharu, yang berhubungan dengan efikasi diri ibu terhadap perawatan bayi baru lahir, diperoleh dalam studi pendahuluan pada bulan Februari 2018, adalah rendahnya cakupan pemberian ASI eksklusif, yakni hanya 55 bayi (40\%) yang 
diberikan ASI eksklusif dari 153 bayi usia 0-11 bulan dan hanya terdapat 9 orang ibu yang melakukan Inisiasi Menyusui Dini (IMD) dari 43 ibu postpartum.

Berdasarkan data terbaru tahun 2019, cakupan ASI eksklusif di Puskesmas Rambangaru sejak bulan Januari sampai April 2019, hanya 43 (15\%) dari 292 orang ibu postpartum yang memberikan ASI eksklusif pada bayi. Hal ini tampak kontras dengan data IMD yang mencakup $100 \%$ dalam setiap bulannya. Dalam empat bulan terakhir, 53 orang (100\%) ibu postpartum melakukan IMD di Puskesmas. Sementara data status gizi balita berdasarkan Bagian Gizi dan KIA Puskesmas Rambangaru bulan Mei 2019, masih terdapat 15 balita (2,5\%) dengan gizi kurang dan 115 balita (19\%) dengan stunting, dari total 606 balita di Puskesmas Rambangaru, Kecamatan Haharu.

Berdasarkan uraian latar belakang di atas, maka diperlukan studi lebih lanjut untuk melihat pengaruh edukasi Paket Cerdas Ibu Menyusui (PCIM) terhadap efikasi diri ibu dalam merawat bayi di Puskesmas Rambangaru. Edukasi kesehatan PCIM merupakan pemberian pendidikan kesehatan dengan media buku dan video yang berisi beberapa materi tentang perawatan bayi usia 0-12 bulan yang meliputi: ASI eksklusif, MP-ASI, pengaturan suhu tubuh normal, pengenalan isyarat, sinyal, dan stimulasi tumbuh kembang bayi usia 0-12 bulan.

Tujuan penelitian ini adalah untuk mengetahui pengaruh edukasi Paket Cerdas Ibu Menyusui (PCIM) terhadap efikasi diri ibu dalam merawat bayi di Puskesmas Rambangaru.

\section{METODE PENELITIAN}

Desain penelitian yang digunakan dalam penelitian ini adalah quasi experiment pre-test and post-test design with control group. Responden penelitian ini adalah ibu primipara yang berusia dewasa awal yakni 18-30 tahun, berpendidikan maksimal SMA, bertempat tinggal di wilayah Puskesmas Rambangaru dan bersedia menjadi responden dengan menandatangani informed consent. Kriteria eksklusi dalam penelitian ini yaitu ibu yang memiliki bayi dengan kelainan bawaan dan berat badan lahir rendah.

Kuesioner yang digunakan dalam penelitian ini yaitu kuesioner Parental Self-Efficacy Scale (PSES) dan Perceived Social Support for Parenting (PSSP). Kuesioner PSES dikembangkan oleh Salonen et al. ${ }^{9}$ dengan 27 pernyataan untuk menggambarkan keyakinan diri ibu dalam merawat bayi. Kuesioner ini menggunakan skala likert 1-6 dengan total skor yang akan dibagi dengan jumlah pertanyaan untuk masing-masing aspek self-efficacy. Hasil uji validitas kuesioner PSES didapatkan $r$ hitung $>r$ tabel $(0,362-0,768>0,361)$, sedangkan reliabilitas instrumen diperoleh nilai Cronbach's Alpha sebesar 0,747 >0,60.

Kuesioner PSSP untuk mengukur dukungan sosial yang diperoleh ibu selama postpartum. PSSP dikembangkan oleh Leerkes dan Crockenberg. ${ }^{10}$ Instrumen ini berisi 8 item pertanyaan yang terbagi ke dalam 4 komponen, yaitu banyaknya bantuan yang didapat (nomor 1 dan 2), kualitas bantuan (nomor 3 dan 4), banyaknya motivasi yang didapat (nomor 5 dan 6), dan 
umpan balik (nomor 7 dan 8). Jawaban yang disediakan dalam bentuk skala Likert 1-5. Interpretasi dari instrumen ini adalah membagi total skor yang didapat dengan jumlah pertanyaan, sehingga diperoleh nilai maksimal $40 .{ }^{10}$ Hasil uji validitas kuesioner PSSP didapatkan $r$ hitung $>r$ tabel $(0,418-0,698>0,361)$ dan nilai reliabilitas diperoleh Cronbach's Alpha sebesar 0,727 $>0,60$.

Ibu primipara yang memenuhi kriteria inklusi sebagai responden, dibagi dalam dua kelompok, yaitu kelompok kontrol dan kelompok intervensi. Penentuan kelompok kontrol dan intervensi dilakukan dengan pengundian sederhana pada responden di desa masing-masing, sehingga setiap desa terwakilkan dalam kelompok kontrol maupun kelompok intervensi. Kegiatan intervensi dilakukan di dalam gedung kantor desa dan Posyandu yang memiliki sarana listrik.

Pada kelompok intervensi, proses penelitian dilakukan dalam tiga sesi; minggu pertama, intervensi diawali dengan penjelasan tentang jalannya penelitian dan cara pengisian kuesioner serta penandatanganan lembar persetujuan sebagai responden (informed consent). Kemudian dilanjutkan dengan pelaksanaan pre-test, mengisi kuesioner efikasi diri dan kuesioner dukungan sosial. Selanjutnya, responden diberi ceramah oleh pemateri menggunakan slide selama 30 menit, pemutaran video 15 menit, diskusi, dan penugasan. Minggu kedua, dilanjutkan dengan kegiatan diskusi dan demonstrasi sehubungan dengan penugasan pada pertemuan pertama. Minggu ketiga jeda, kemudian pada minggu ke empat dilanjutkan dengan pengambilan data post-test. Post-test dilakukan dengan mendatangi responden di rumah masing-masing.

Sementara pada kelompok kontrol juga diberikan penjelasan tentang jalannya penelitian, cara mengisi kuesioner, penandatanganan lembar persetujuan responden, pengisian lembar kuesioner pre-test, dan data demografi responden. Kemudian dilanjutkan dengan pemberian intervensi berupa penyuluhan kesehatan rutin oleh petugas Puskesmas pada minggu pertama. Pada minggu ketiga, dilanjutkan pengambilan data post-test dengan mendatangi responden ke rumah masing-masing.

Penelitian ini dilaksanakan setelah mendapatkan ijin kelayakan etik penelitian dari komite etik FK-KMK UGM, dengan nomor surat: KE/FK/0435/EC 2019, dan surat ijin penelitian dari Dinas Penanaman Modal Perijinan dan Pelayanan Terpadu Satu Pintu Kabupaten Sumba Timur dengan nomor: 41/DPMPTSP/-IP/III/2019.

Penyajian data dalam penelitian ini meliputi data kategorik dan data numerik. Data kategorik berupa tingkat pendidikan Ibu, dianalisis dan disajikan dalam bentuk distribusi, frekuensi, dan persentase. Data numerik terdiri dari usia lbu, skor efikasi diri, dan skor dukungan sosial, disajikan dalam bentuk mean dan standar deviasi (SD). Normalitas data dianalisis menggunakan uji Saphiro-Wilk dengan sampel kurang dari 50 untuk masing-masing kelompok. Uji statistik paired t-test dilakukan untuk menguji beda mean pada satu kelompok yang sama, 
yakni perbedaan skor efikasi diri ibu sebelum dan setelah intervensi pada kelompok kontrol dan intervensi, karena data terdistribusi secara normal. Sementara itu, untuk mengetahui perbedaan mean pada kelompok yang berbeda, yakni perbedaan skor efikasi diri ibu sebelum dan setelah intervensi, serta selisih skor efikasi diri setelah intervensi antara kelompok kontrol dan kelompok intervensi, dilakukan uji statistik menggunakan independent $t$-test. Uji statistik Spearman-rho dilakukan untuk melihat korelasi antara dukungan sosial dan efikasi diri ibu primipara. Uji Spearman digunakan karena salah satu data tidak terdistribusi normal yaitu data dukungan sosial.

\section{HASIL}

Responden yang bersedia terlibat dalam penelitian ini berjumlah 60 orang ibu primipara. Karakteristik responden penelitian meliputi, umur, pekerjaan, tingkat pendidikan dan nilai dukungan sosial responden, tersaji dalam Tabel 1.

Berdasarkan Tabel 1, dapat diketahui bahwa karakteristik demografi responden penelitian yang meliputi umur, tingkat pendidikan, maupun dukungan sosial, pada semua kelompok, secara statistik memiliki karakteristik yang homogen atau setara dengan nilai $p>0,05$. Hal ini menunjukkan bahwa tidak ada perbedaan karakteristik pada kedua kelompok intervensi dan kelompok kontrol. Tabel 1 di bawah ini menggambarkan bahwa status pendidikan responden tampak didominasi oleh pendidikan dasar pada kedua kelompok responden dan tidak ada yang tidak bersekolah. Demikian halnya dengan distribusi umur responden, dari tabel 1 menunjukkan distribusi yang normal pada kedua kelompok, dengan rentang umur berada pada kategori 18-27 tahun pada dua kelompok, yang merupakan rata-rata usia ibu primipara, pada kelompok kontrol berada pada rentang 21,8 tahun dan 22,3 tahun pada kelompok intervensi. Sementara pekerjaan responden pada kedua kelompok, semuanya sebagai lbu rumah tangga.

Tabel 1. Karakteristik subjek penelitian di Puskesmas Rambangaru Tahun $2019(n=60)$

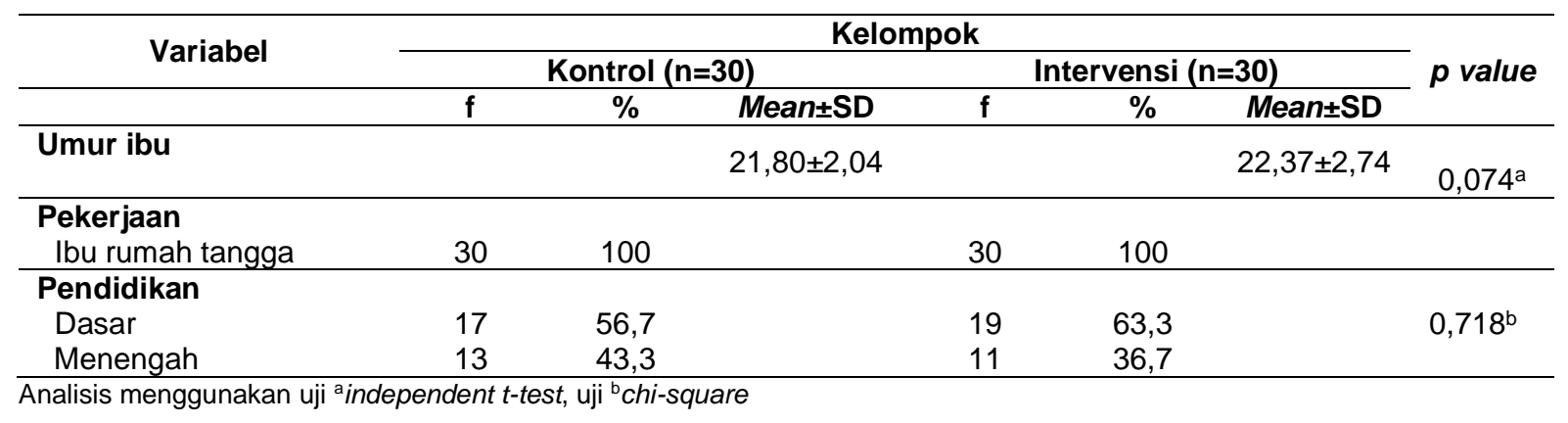

Hasil uji perbedaan nilai efikasi diri ibu primipara sebelum dan sesudah diberikan intervensi pada kedua kelompok responden, dapat dilihat pada Tabel 2 di bawah ini. 
Tabel 2. Hasil uji beda skala efikasi diri sebelum dan sesudah intervensi di Puskesmas Rambangaru Tahun $2019(n=60)$

\begin{tabular}{|c|c|c|c|c|}
\hline \multirow{3}{*}{$\begin{array}{c}\text { Variabel } \\
\text { efikasi diri ibu }\end{array}$} & \multicolumn{4}{|c|}{ Kelompok responden } \\
\hline & \multicolumn{2}{|c|}{ Kontrol } & \multicolumn{2}{|c|}{ Intervensi } \\
\hline & Mean \pm SD & $p$ value & Mean \pm SD & $p$ value \\
\hline Total pre-test & $3,45 \pm 0,21$ & $0,001^{*}$ & $3,51 \pm 0,23$ & $0,001^{*}$ \\
\hline $\begin{array}{l}\text { Total post-test } \\
\text { Aspek kognitif }\end{array}$ & $4,62 \pm 0,26$ & & $5,49 \pm 0,15$ & \\
\hline Pre-test & $3,10 \pm 0,30$ & $0,003^{*}$ & $3,17 \pm 0,37$ & $0,001^{*}$ \\
\hline Post-test & $3,47 \pm 0,50$ & & $5,30 \pm 0,46$ & \\
\hline Aspek afektif & & & & \\
\hline Pre-test & $4,10 \pm 0,40$ & $0,001^{*}$ & $4,23 \pm 0,43$ & $0,001^{*}$ \\
\hline Post-test & $5,17 \pm 0,46$ & & $5,40 \pm 0,49$ & \\
\hline Aspek keterampilan & & & & \\
\hline Pre-test & $3,50 \pm 0,57$ & $0,001^{*}$ & $3,50 \pm 0,50$ & $0,001^{*}$ \\
\hline Post-test & $4,47 \pm 0,57$ & & $6,00 \pm 0,00$ & \\
\hline
\end{tabular}

Berdasarkan hasil uji pada Tabel 2 di atas, didapatkan nilai rata-rata sebelum intervensi $3,51 \pm 0,23$ pada kelompok intervensi. Skala terendah pada aspek kognitif 3,17 dan tertinggi pada aspek afektif 4,23. Sementara pada kelompok kontrol diperoleh nilai rata-rata 3,45 $\pm 0,21$. Skala terendah pada aspek kognitif 3,10 dan tertinggi pada aspek afektif 4,10. Rendahnya nilai efikasi diri kedua kelompok pada aspek kognitif, teridentifikasi melalui capaian nilai yang rendah (2-3) pada item pernyataan nomor 5 dan 6 , sehubungan dengan stimulasi tumbuh kembang anak, yaitu "Saya tahu tahap pertumbuhan dan perkembangan bayi secara normal" dan "Saya tahu cara stimulasi tumbuh kembang yang cocok untuk bayi saya".

Dalam pengukuran post-test setelah intervensi pada kedua kelompok responden, terdapat peningkatan skala efikasi diri kelompok kontrol menjadi 4,62, dengan skala tertinggi pada aspek afektif 5,17 , sedangkan pada kelompok intervensi juga meningkat menjadi 5,49 dengan skala tertinggi pada aspek keterampilan, yaitu 6,00. Secara statistik terdapat perbedaan yang bermakna pada nilai rata-rata efikasi diri pada kedua kelompok responden sebelum dan sesudah diberikan intervensi dengan nilai $p=0,001(p<0,05)$. Perbedaan selisih nilai efikasi diri ibu primipara setelah diberikan intervensi pada kedua kelompok, ditampilkan dalam Tabel 3 berikut ini.

Berdasarkan paparan Tabel 3, didapatkan gambaran hasil post-test nilai efikasi diri setelah dua minggu pemberian intervensi, diperoleh selisih nilai rerata skala efikasi diri responden pada kedua kelompok 0,81 poin. Dengan $p=0,001$ disimpulkan terdapat perbedaan yang signifikan pada kedua kelompok. Berdasarkan hasil di atas dapat disimpulkan bahwa edukasi Paket Cerdas Ibu Menyusui (PCIM) pada kelompok intervensi, terbukti berpengaruh terhadap peningkatan efikasi diri ibu primipara dalam merawat bayi baru lahir, dibandingkan dengan penyuluhan konvensional Puskesmas pada kelompok kontrol, di Puskesmas Rambangaru, Kecamatan Haharu, Kabupaten Sumba Timur, Nusa Tenggara Timur. 
Tabel 3. Nilai selisih efikasi diri ibu sebelum dan setelah intervensi pada kelompok kontrol dan intervensi

\begin{tabular}{lccc}
\hline \multirow{2}{*}{ Variabel/Aspek Efikasi Diri } & \multicolumn{2}{c}{ Selisih Nilai } & \multirow{2}{*}{ Nilai $\boldsymbol{p}$ antar kelompok } \\
\cline { 2 - 3 } & Kontrol & Intervensi & $0,001^{*}$ \\
\hline Kognitif & $0,47 \pm 0,57$ & $2,27 \pm 0,69$ & 0,621 \\
Afektif & $1,03 \pm 0,55$ & $1,10 \pm 0,48$ & $0,001^{*}$ \\
Keterampilan & $0,93 \pm 0,74$ & $2,33 \pm 0,66$ & $0,001^{*}$ \\
Total Efikasi Diri & $1,17 \pm 0,38$ & $1,98 \pm 0,28$ & \\
\hline
\end{tabular}

Ket: *Uji Independent $t$-test

Pada kedua domain (kognitif dan ketrampilan) didapatkan p-value 0,001. Dapat disimpulkan bahwa pada kedua domain tersebut terdapat perbedaan yang signifikan di kedua kelompok. Peningkatan skala tertinggi pada kedua kelompok terdapat pada aspek keterampilan yaitu 0,93 pada kelompok kontrol dan 2,33 pada kelompok intervensi. Namun, pada aspek afektif tidak terdapat perbedaan yang signifikan antara dua kelompok dengan nilai $p=0,621$.

Dukungan sosial dalam penelitian ini merupakan variabel perancu yang diukur menggunakan uji korelasi Spearman's rho, karena data tidak terdistribusi dengan normal, karena dalam uji normalitas Saphiro Wilk diperoleh nilai $p=0,004$ pada kelompok kontrol dan $p=0,003$ pada kelompok intervensi (Tabel 4).

Tabel 4. Uji korelasi antara dukungan sosial dengan efikasi diri ibu primipara setelah intervensi pada kelompok kontrol dan kelompok intervensi $(n=60)$

\begin{tabular}{lcccc}
\multicolumn{4}{c}{ pada kelompok kontrol dan kelompok intervensi $(\mathbf{n = 6 0})$} \\
\cline { 2 - 5 } Hubungan Variabel & $\begin{array}{c}r \\
\text { hitung }\end{array}$ & $\boldsymbol{p}$-value & $\begin{array}{c}\mathbf{r} \\
\text { hitung }\end{array}$ & $\boldsymbol{p}$-value \\
\hline Efikasi Diri & 0,001 & 0,997 & 0,162 & 0,392 \\
Dukungan sosial & & & & \\
\hline Keterangan: diuji dengan korelasi Spearman-rho & &
\end{tabular}

Berdasarkan hasil uji korelasi Spearman dalam tabel di atas, diperoleh nilai $p=0,392$ pada kelompok intervensi dan $p=0,997$ pada kelompok kontrol. Hal ini menunjukkan bahwa secara statistik tidak ada hubungan yang bermakna antara dukungan sosial keluarga terhadap efikasi diri ibu primipara. Dengan demikian, dapat disimpulkan bahwa peningkatan efikasi diri ibu primipara bukan dipengaruhi oleh dukungan sosial keluarga, tetapi dipengaruhi oleh intervensi edukasi kesehatan Paket Cerdas Ibu Menyusui (PCIM) pada kelompok intervensi dan penyuluhan konvensional Puskesmas pada kelompok kontrol.

\section{PEMBAHASAN}

Hasil analisis karakteristik responden pada kedua kelompok menunjukkan bahwa tidak ada perbedaan karakteristik yang signifikan antara kelompok kontrol dan kelompok intervensi. Dengan demikian, terdapat homogenitas atau kesetaraan data dalam dua kelompok responden sebelum diberi perlakuan. Pengaruh karakteristik responden terhadap pemberian edukasi kesehatan Paket Cerdas Ibu Menyusui telah dikontrol dengan kriteria inklusi dan 
eksklusi dalam skrining sampel. Karakteristik responden dalam penelitian ini meliputi usia, pekerjaan, berat badan bayi saat ini, dan status pendidikan. Rata-rata usia ibu primipara di kedua kelompok berada pada rentang usia 18-27 tahun dan berat badan bayi saat itu tidak ada yang kurang dari 2.500 gram. Pekerjaan ibu juga sama homogen, yakni sebagai ibu rumah tangga, yang berarti ibu tidak bekerja. Penelitian yang dilakukan oleh Wardhani ${ }^{11}$ menyebutkan bahwa ibu yang tidak bekerja memiliki skor efikasi diri yang lebih tinggi jika dibandingkan dengan ibu yang bekerja karena ibu yang tidak bekerja memiliki lebih banyak waktu dalam memberikan pengasuhan kepada bayinya.

Hasil pengukuran menunjukkan peningkatan nilai efikasi diri ibu setelah intervensi pada kedua kelompok responden. Kelompok intervensi meningkat secara signifikan lebih tinggi dibandingkan kelompok kontrol. Aspek kognitif merupakan salah satu aspek efikasi diri ibu yang meningkat setelah intervensi dilakukan. Aspek ini merupakan aspek dengan nilai terendah sebelum intervensi pada kedua kelompok. Perbedaan ini terjadi karena kelompok intervensi diberikan edukasi kesehatan Paket Cerdas lbu Menyusui (PCIM) dalam bentuk video dan buku, disertai diskusi kelompok dalam pertemuan kedua setelah intervensi. Adapun isi buku dan video berupa materi perawatan bayi baru lahir yang meliputi: pemberian ASI eksklusif, MP-ASI, siklus tidur bayi, stimulasi tumbuh kembang bayi, dan mempertahankan suhu normal bayi. Melalui edukasi ini, efikasi diri ibu primipara meningkat dalam melakukan tugas perawatan pada bayinya.

Dalam penelitian Astutiningrum ${ }^{12}$ ada empat hal utama yang berpengaruh langsung pada efikasi diri seseorang yaitu: pengalaman pribadi, pengalaman orang lain, persuasi verbal, dan kondisi emosional. ${ }^{13}$ Dalam penelitian ini, hal yang berpengaruh dalam peningkatan efikasi diri ibu primipara berupa pembelajaran melalui persuasi verbal dengan pemberian edukasi kesehatan oleh tenaga kesehatan bagi kedua kelompok. Penyuluhan secara umum merupakan upaya yang direncanakan untuk memberikan pengaruh kepada orang lain baik individu, kelompok, maupun masyarakat, agar mereka melakukan apa yang dikehendaki oleh pemberi penyuluhan. ${ }^{14}$ Dalam penelitian ini, penyuluhan dan diskusi diberikan oleh Bidan koordinator KIA di Puskesmas Rambangaru dan difasilitasi oleh perawat Puskesmas pada kelompok intervensi. Tenaga perawat di Puskesmas dapat menjadi pendidik, penyuluh kesehatan, penemu kasus, pelaksana konseling keperawatan, sekaligus role model. ${ }^{15}$ Dalam sesi diskusi pada pertemuan kedua pada kelompok intervensi, responden diberikan kesempatan seluas-luasnya untuk mendiskusikan hal-hal yang berhubungan dengan perawatan bayi baru lahir, berupa tantangan dan hambatan yang dihadapi oleh ibu primipara. Pada kesempatan ini, ibu primipara mendapatkan kesempatan untuk melihat langsung demonstrasi perawatan bayi baru lahir, terlibat dalam diskusi dan kesempatan untuk mempraktikkan ulang cara merawat bayi baru lahir. Diskusi kelompok juga memberikan kesempatan bagi ibu untuk belajar dari pengalaman anggota lain dalam kelompok tentang 
keberhasilan yang telah dicapai dalam merawat bayi baru lahir. Tenaga kesehatan dapat menjadi fasilitator dan membantu ibu primipara dengan dukungan informasi verbal untuk meningkatkan keyakinan dirinya dalam merawat anak sehubungan dengan tugas baru sebagai orang tua. Persuasi verbal yang bersifat positif sebagai bentuk dukungan dari tenaga kesehatan, dapat membantu ibu untuk meningkatkan parenting self-efficacy. ${ }^{16}$

Peningkatan aspek kognitif pada kelompok kontrol ini bisa terjadi karena adanya program pemerintah daerah yang mewajibkan setiap ibu hamil untuk melahirkan di fasilitas kesehatan yang memadai, minimal di Puskesmas, sehingga dipastikan bahwa ibu primipara mendapatkan penyuluhan kesehatan tentang perawatan bayi baru lahir dan masa nifas dari petugas kesehatan yang menolong persalinannya.

Perubahan efikasi diri ibu dapat juga dilihat dari aspek afektif, yang menunjukkan perbedaan bermakna sebelum dan sesudah diberikan intervensi. Aspek ini merupakan aspek dengan nilai paling tinggi pada kelompok kontrol. Namun, jika dibandingkan dengan nilai efikasi pada kelompok intervensi, didapatkan perbedaan yang tidak bermakna di antara keduanya. Hal ini disebabkan karena reaksi emosional seseorang dapat menimbulkan keyakinan berdasarkan pengalaman sebelumnya, belajar dari orang terdekat atau figur yang dianggap berkompeten.

Dalam penelitian ini intervensi diberikan dalam bentuk diskusi, penugasan dan role play, sehingga ibu primipara memiliki kesempatan untuk mendemonstrasikan dan mendiskusikan hal-hal yang tidak dipahami selama merawat bayi baru lahir. Setelah intervensi, sebagian besar ibu primipara pada kedua kelompok ini merasa yakin akan kemampuannya dalam merawat bayi. Hal ini tampak pada item pernyataan nomor 12, 13, 15, 17, dan 18 yang berisi kemampuan ibu untuk mengenal dan merespons keinginan, temperamen, dan perilaku bayi dalam situasi tertentu. Kedua kelompok ini mendapatkan paparan yang sama terhadap sumber informasi dari petugas kesehatan pada saat melahirkan di Puskesmas. Hal lain yang berkaitan dengan peningkatan aspek afektif pada kelompok kontrol, yakni masa postpartum dari ibu primipara yang sudah melewati dua minggu pertama, sehingga sudah memiliki pengalaman yang cukup dan mendapatkan dukungan dari keluarga dalam merawat bayi. Faktor lain yang memengaruhi status emosional ibu primipara adalah pengetahuan dalam mempersiapkan diri menghadapi proses persalinan. Backstrom et al.,17 mengemukakan bahwa dukungan berupa informasi dan pengetahuan dari petugas kesehatan yang diberikan secara individu, dapat meningkatkan kepuasan dan kepercayaan diri lbu.

Penelitian ini juga menunjukkan peningkatan pada nilai efikasi diri ibu pada aspek keterampilan pada kelompok intervensi dan kelompok kontrol yang bermakna, terutama pada kelompok intervensi, merupakan nilai yang tertinggi dari semua aspek. Peningkatan keterampilan ini tidak terlepas dari intervensi diskusi dan demonstrasi langsung yang difasilitasi oleh pemateri pada saat pertemuan kedua pada kelompok intervensi. Pada 
kesempatan ini, responden dapat dengan leluasa melakukan praktik perawatan bayi bersama bidan fasilitator. Pengalaman melakukan secara langsung dan berulang-ulang akan memberikan kepercayaan diri bagi ibu untuk dapat melakukannya secara mandiri di rumah. Kemampuan seseorang dalam melakukan aktivitas yang spesifik biasanya terbentuk dari pengetahuan dan sikap yang pernah didapatkan dan dilakukan sebelumnya. ${ }^{18}$

Materi intervensi juga dikemas dalam bentuk video, untuk memudahkan ibu dalam mempelajari atau menontonnya di mana saja. Pada penelitian Joventino et al., ${ }^{8}$ mengungkapkan bahwa edukasi kesehatan menggunakan video memberi efek yang bermakna dalam peningkatan efikasi diri lbu. Beberapa penelitian lainnya menyatakan bahwa efikasi diri ibu berpengaruh terhadap pertumbuhan dan perkembangan fisik, psikologis, dan sosial anak yang optimal.

Berdasarkan hasil penelitian ini menunjukkan bahwa perubahan efikasi diri ibu primipara pada kolompok intervensi lebih tinggi dibandingkan dengan kelompok kontrol setelah intervensi. Maka, direkomendasikan penggunaan edukasi kesehatan PCIM pada layanan kesehatan komunitas, khususnya dalam layanan kesehatan ibu dan anak di Puskesmas. Edukasi kesehatan menggunakan sarana audiovisual dilengkapi dengan diskusi dan role play, efektif dalam meningkatkan efikasi diri ibu primipara dalam merawat bayi. Metode yang sangat penting dalam intervensi PCIM adalah diskusi dan demonstrasi langsung yang diperagakan oleh pemateri dan diikuti oleh responden, sehingga dapat meningkatkan pengetahuan, keyakinan, dan menambah keterampilan setelah melakukan redemonstrasi di bawah bimbingan langsung oleh pemateri dan asisten penelitian saat kegiatan berlangsung.

Hasil analisis data menunjukkan bahwa tidak ada hubungan yang bermakna antara dukungan sosial dengan nilai efikasi diri ibu primipara dalam merawat bayi baru lahir. Dalam penelitian ini murni disebabkan oleh intervensi yang diberikan pada kedua kelompok, yakni edukasi kesehatan Paket Cerdas Ibu Menyusui (PCIM) pada kelompok intervensi dan penyuluhan konvensional Puskesmas pada kelompok kontrol. Hal ini disebabkan karena intervensi yang diberikan pada kelompok intervensi dan kontrol masih baru dengan rentang waktu dua minggu setelah intervensi, sedangkan dukungan sosial dirasakan bermakna dan intens ketika ibu primipara berada dalam dua minggu masa postpartum. Hubungan yang tidak bermakna dapat juga disebabkan oleh usia bayi yang pada umumnya berusia lebih dari dua bulan, sehingga ibu sudah berpengalaman dalam mengasuh dan merawat bayi baru lahir bahkan telah mencapai beberapa keberhasilan dalam merawat bayinya. ${ }^{9,19} \mathrm{Hal}$ ini dapat berpengaruh pada korelasi dukungan sosial terhadap efikasi diri, dibandingkan bila pengukuran skala efikasi diri ibu dan dukungan sosial keluarga dilakukan pada awal postpartum.

Adanya hubungan yang tidak bermakna antara dukungan sosial dan efikasi diri ibu dalam penelitian ini juga dipengaruhi oleh kemampuan ibu dalam menggunakan dukungan sosial 
yang diperoleh secara optimal. Namun, ketika ibu memiliki efikasi diri yang sudah baik, maka dukungan sosial tidak lagi dibutuhkan atau cenderung tidak digunakan.

\section{KESIMPULAN DAN SARAN}

Dalam penelitian ini, disimpulkan bahwa terdapat pengaruh pemberian edukasi kesehatan Paket Cerdas Ibu Menyusui (PCIM) terhadap peningkatan efikasi diri ibu primipara dalam merawat bayi baru lahir di Puskesmas Rambangaru, Sumba Timur. Terdapat perbedaan yang signifikan pada nilai efikasi diri ibu primipara dalam aspek kognitif dan keterampilan, sedangkan pada aspek afektif tidak ada perbedaan bermakna, antara kelompok kontrol dan kelompok intervensi. Selain itu, dapat disimpulkan bahwa tidak ada hubungan yang bermakna antara efikasi diri dan dukungan sosial keluarga, pada ibu primipara dalam merawat bayi baru lahir.

Saran bagi koordinator program Kesehatan Ibu dan Anak (KIA) di Puskesmas dapat menggunakan video dan buku PCIM sebagai sarana untuk meningkatkan pengetahuan dan keterampilan ibu primipara dalam merawat bayi baru lahir oleh tenaga Puskesmas, dalam upaya meningkatkan efikasi diri ibu dalam merawat bayi di wilayah Puskesmas Rambangaru, Kecamatan Haharu, Kabupaten Sumba Timur.

Saran bagi responden, sebaiknya dapat mempertahankan dan meningkatkan aspek keterampilan dan pengetahuan yang telah dimiliki oleh responden saat ini, sehubungan dengan perawatan bayi baru lahir, untuk mengatasi tantangan yang dihadapi selama masa awal postpartum dan perawatan bayi baru lahir secara umum. Kemudian, agar memanfaatkan buku dan video secara optimal dan mencari sumber informasi kesehatan yang valid dari tenaga kesehatan sehubungan dengan tahap perkembangan bayi dan cara stimulasi tumbuh kembang bayi sesuai dengan usia.

Saran bagi peneliti, diharapkan agar dapat melakukan penelitian lanjutan untuk mengeksplorasi beberapa hal yang belum terungkap dalam penelitian saat ini, seperti korelasi yang tidak bermakna antara dukungan sosial dengan efikasi diri ibu dan perbedaan efikasi diri ibu yang tidak bermakna dari aspek afektif antara kelompok kontrol dan kelompok intervensi.

\section{UCAPAN TERIMAKASIH}

Ucapan terima kasih peneliti sampaikan kepada semua pihak yang telah membantu dan terlibat dalam penelitian ini sehingga penelitian berjalan lancar.

\section{DAFTAR PUSTAKA}

1. Shorey S, Chan SWC, Chong YS, He HG. Maternal Parental Self-Efficacy in Newborn Care and Social Support Needs in Singapore: A Correlational Study. J Clin Nurs. 2014; 23(15-16): 2272-83.

2. Pollard D, Guill M. The Relationship between Baseline Self-Efficacy and Breastfeeding Duration. South Online J Nurs. 2009; 9(4).

3. Dennis C. The Breastfeeding Self-Efficacy Scale: Psychometric Assessment of The Short Form. J Obstet Gynecol Neonatal Nurs. 2003; 32(6): 734-44.

4. Buxton, KE, Gielen, AC, Faden, RR, Brown, $\mathrm{CH}$, Paige, DM, Chawalow, AJ. Women Intending to Breastfeed: 
Predictors of Early Infant Feeding Experiences. Am J Prev Med. 1991; 7: 101-6.

5. Zakiah, Rasyad AS, Sujatno HRM. Efikasi Diri dan Lama Pemberian Air Susu lbu Saja Selama 2 Bulan Postpartum. Gaster. 2012; 9(2): 7-16.

6. World Health Organization. WHO Recommendations on Postnatal Care of The Mother and Newborn. 2014.

7. Citrawati NK, Widyandana, Hapsari ED. Pengaruh Pendidikan Kesehatan dengan Media Audiovisual Manajemen Laktasi terhadap Tingkat Pengetahuan dan Self-Efficacy lbu Menyusui. 2015.

8. Joventino ES, Ximenes LB, da Penha JC, Andrade LC de O, de Almeida PC. The Use of Educational Video to Promote Maternal Self-Efficacy in Preventing Early Childhood Diarrhoea. Int J Nurs Pract. 2017; 23(3): 17.

9. Salonen AH, Kaunonen M, Åstedt-Kurki P, Järvenpää AL, Isoaho H, Tarkka MT. Parenting Self-Efficacy After Childbirth. J Adv Nurs. 2009; 65(11): 2324-36.

10. Leerkes, EM, Crockenberg SC. The Development of Maternal Self-Efficacy and Its Impact on Maternal Behavior. Infancy. 2002; 3(2): 227-47.

11. Wardhani MA. Gambaran Tingkat Self-Efficacy untuk Menyusui pada Ibu Primigravida [Thesis]. Jakarta: Fakultas IImu Keperawatan Universitas Indonesia; 2012.

12. Astutiningrum D, Hapsari ED. Pengaruh Konseling terhadap Parenting Self-Efficacy pada Ibu Postpartum dengan Sectio Caesarea. 2015.

13. Bandura A. Self-Efficacy: The Exercise of Control (Fifth Print). New York: W.H. Freeman and Company; 1997.

14. Notoatmodjo S. Promosi Kesehatan \& Perilaku. Jakarta: Rineka Cipta. 2007.

15. Efendi F, Makhfudli. Keperawatan Kesehatan Komunitas. Jakarta: Salemba Medika; 2009.

16. Leahy-Warren P, Mccarthy G, Corcoran P. First-Time Mothers: Social Support, Maternal Parental Self-Efficacy and Postnatal Depression. J Clin Nurs. 2012; 21(3-4): 388-97.

17. Bäckström CA, Wahn EIH, Ekström AC. Two Sides of Breastfeeding Support: Experiences of Women and Midwives. Int Breastfeed J. 2010 Nov; 5(1): 1-8.

18. Maulana HDJ. Promosi Kesehatan. Jakarta: EGC; 2009.

19. Troutman B, Moran TE, Arndt S, Johnson RF, Chmielewski M. Development of Parenting Self-Efficacy in Mothers of Infants with High Negative Emotionality. Infant Ment Health J. 2012 Jan; 33(1): 45-54. 